\title{
and Health (ICASSETH 2019) The Influence of Giving Information on Diarrhea Management to the Knowledge and Attitude of the Mother Carrying Infants in the Primary Health Care in Sitopeng Cirebon
}

\author{
Rais Sutan Muhammad Zain, Risnandya Primanagara*, Yandri Naldi, Nurbaiti Nurbaiti \\ Faculty of Medicine \\ Universitas Swadaya Gunung Jati \\ Cirebon, Indonesia \\ *primanagara@gmail.com
}

\begin{abstract}
Diarrhea is one of the major public health problems in Indonesia. The high incidence of diarrhea can be affected by several factors such as lack of knowledge and treatment of diarrhea in children under five years old. Giving information of diarrhea management can reduce its incidence on children. The objective of this study was to determine the influence of counseling for the treatment of diarrhea to the knowledge and attitude of mothers to bring children under five years to Primary Health Care. The method used in this research is a quasi-experimental method. Mothers with children were taken as Subjects. A simple random sampling was used to choose 96 subjects then given questionnaires about the knowledge about the treatment of diarrhea. The results was analyzed using the Wilcoxon test and shows the significant value of under 0.001 . The less than 0.05 significant value shows differences in knowledge and attitude before and after given information. The level of mother knowledge about the treatment of diarrhea after given counseling higher than the mother's knowledge about the treatment of diarrhea before being given counseling.
\end{abstract}

Keywords: diarrhea, management, information, counseling

\section{INTRODUCTION}

Diarrhea is a condition when a person experiences soft or runny consistency defecation, or even liquid, with frequent concurrency, three times a day or more in one day. Causes of diarrhea are multifactorial, such as infection, malabsorption, but most of all are caused by infection. In some cases of diarrhea, a person who has diarrhea and has just recovered from it, the diarrhea can be reoccurred repeatedly. This was caused due to incomplete healing, persistent infection, and another pathogenic reinfection [1]. Diarrhea is one of the most occurring health problems the world. Globally, diarrhea is the second cause of death after pneumonia, especially in developing countries. According to UNICEF (United Nations Children's Fund) and WHO (World Health Organization) in 2009 , diarrhea is the second cause of death on toddlers, number 3 in infants, and number 5 for all ages. What was obtained from UNICEF data tells us that 1.5 million children died each year from diarrhea [2]
Based on a morbidity survey conducted by the Diarrhea Sub directorate, Ministry of Health of Republic of Indonesia in 2011, the largest proportion of diarrhea sufferers in children under five are in the age group of $6-11$ months which is $21.65 \%$ and the age group of $12-17$ months is $14.43 \%$, age group 24-29 months is $12.37 \%$. This is a health problem that needs consideration, especially diarrhea that is commonly suffered by infants and toddlers, which can be the biggest contributor to death. Hygiene and environmental sanitation, awareness of parents to behave on a clean and healthy life and breastfeeding are important factors in reducing diarrhea morbidity in infants [3].

Cirebon Health Office on 2010 release that 10.800 person got diarrhea, and from the work area of Public Heath Care, most cases happened in Sitopeng area, reaching 1.148 cases. Therefore, a good attitude of diarrhea is important to reduce fatal or even mortal cases [4].

The high case number still occurs, despite the government provide principle handling for diarrhea. Public health care was encouraged to act the Five Steps to Stop Diarrhea or LINTAS (Lima Langkah Tuntaskan Diare). It is consisting of giving oralit, giving zinc, continuing breastfeeding and Foods, Antibiotics medications, and educating caregiver. Those programs are expected to decrease the risk of death caused by diarrhea $[5,6]$.

\section{METHODS}

This research is using quasi experimental method, with randomized control group, pre-post design. The research took on mother carrying infants, that was questioned on how their management on diarrhea, and then given information on how to manage diarrhea properly. After around 4 months, from January to April 2016, a re-questioning was taken. This research took place in Sitopeng area. The research protocol was acknowledged by the Dean of Medical Faculty of Universitas Swadaya Gunung Jati. And given Ethical Clearance from Health Research Ethical Committee on Medical Faculty of Universitas Swadaya Gunung Jati. 
Target population of this research was every mother having 1-5 years old toddler. Samples taken from the population using Simple random sampling, to ensure every mother got the same opportunity to become research subject. Sample size was determined using proportion estimation technique, resulting 96 respondents should be taken.

Data was taken and analyzed using Paired T Test Analysis, using Computer Based Statistical Software.

\section{RESULTS}

Research survey found that before the information management and counseling was given, there was $5,2 \%$ of the respondents indicated deficient attitude in diarrhea, and 24 persons, or $25 \%$ of the respondent's attitude in diarrhea are fair, and only $69,8 \%$ of the respondents are having good attitude on diarrhea.

After given the Information Management on diarrhea, near the end of the research time, the mindset of people should have changed. Therefore, the survey was re taken to the respondents, and the numbers was change. The survey after the information was resulted in no subject was having deficient attitude, $26 \%$ considered fair attitude in diarrhea, and about $74 \%$ samples of subject had good attitude in diarrhea. The overall results of the research were described in table 1 .

TABLE I. ATTITUDE DISTRIBUTION ON DIARRHEA

\begin{tabular}{|l|l|l|l|l|}
\hline \multirow{2}{*}{$\begin{array}{c}\text { Attitude on } \\
\text { diarrhea }\end{array}$} & \multicolumn{2}{c|}{ Pre Information } & \multicolumn{2}{c|}{ Post Information } \\
\cline { 2 - 5 } & Frequency & Percentage & Frequency & Percentage \\
\hline $\begin{array}{l}\text { Deficient } \\
<56\end{array}$ & 5 & 5,2 & 0 & 0 \\
\hline $\begin{array}{l}\text { Fair } \\
56-75\end{array}$ & 24 & 25 & 25 & 26 \\
\hline $\begin{array}{l}\text { Good } \\
76-100\end{array}$ & 67 & 69,8 & 71 & 74 \\
\hline Total & 96 & 100 & 96 & 100 \\
\hline
\end{tabular}

The results were analyzed using computer aided Statistic, and since the data is categorical, A Wilcoxon test was intended. The test generate the $\mathrm{p}$ value is less than 0,001 , so we can conclude that there is significant difference on Responding diarrhea between before and after the Information was given to the subjects bringing the toddlers to Sitopeng Public health center in Cirebon City.

Although before the information given, overall attitude in diarrhea is good, but there are several subjects that had deficient attitude in diarrhea care. This analysis shows that the information given is bringing better attitude in diarrhea care.

The research shows that better knowledge and attitude in diarrhea care should be encouraged. This can be resulting in better health quality in Sitopeng area as the responsibility of Sitopeng Public Health Care $[4,7,8]$. Towards this results, there should be more inquisitive research in this area of expertise, to gather more knowledge in health [9]. Furthermore, it can be related to other research that an encouragement to the health stakeholders can increase more knowledge in this area, not only related to diarrhea, but also in general public health, including nutrition and healthy lifestyle [10,11]. The management of the health promotion and information management should be emphasizing thoroughly to covers health of under-five children [12,13].

\section{DISCUSSIONS}

This results are similar with earlier research that shows negative perception in diarrhea care risking a bad attitudes 3,5 times higher than positive perception. Another study showed that mothers who had less knowledge had the chance of her toddlers got diarrhea is $38.9 \%$ [14], while mothers with good knowledge had a chance her toddlers got diarrhea was $14.9 \%$. A Research conducted by Haroun [15], the level of knowledge of mothers before counseling was $35 \%$, and after counseling increased to $91 \%$. The prevalence of diarrhea before counseling is $53 \%$, and after counseling becomes $47 \%$. The importance of information on managing diarrhea able to encourage mother's carrying infants to properly care the diarrhea.

\section{CONCLUSIONS}

The discussions above lead for the conclusion of this research. The indubitably small $\mathrm{p}$ value on the correlation shows a significant difference on level of knowledge. The level of mother knowledge about the treatment of diarrhea after given counseling is higher than the mother's knowledge about the treatment of diarrhea before being given counseling. In other words, counseling is giving a good impact on better treatment in diarrhea.

\section{REFERENCES}

[1] Ministry of Health Republic Indonesia, Pedoman Tatalaksana Diare, Jakarta, 2012

[2] Ministry of Health Republic Indonesia, Situasi Diare di Indonesia Jakarta, 2011

[3] Ministry of Health Republic Indonesia, Profil kesehatan republik indonesia tahun 2011, Jakarta, 2011

[4] E. Riyanto and R.F.N. Adifa, "Hubungan Tingkat Pengetahuan, Pendidikan, Dan Pola Hidup Bersih Dan Sehat Ibu Terhadap Kejadian Diare Pada Balita Di Puskesmas Sitopeng Kota Cirebon,” Tunas Med. J. Kedokt. Kesehatan, vol. 3, 2016.

[5] Ministry of Health Republic Indonesia, Pengendalian Diare dan Infeksi Saluran Pencernaan, Jakarta, 2011.

[6] I.H. Wirandoko, S.N. Fauzah, B. Wibisono, and I. Syakhruddin, "Faktor penentu status gizi pada anak usia 2-5 tahun di wilayah kerja puskesmas Tlogosari Wetan Kecamatan Pedurungan, Kota Semarang tahun 2007,' Tunas Medika Jurnal Kedokteran \& Kesehatan, vol. 2, no. 1, 2016.

[7] Y. Naldi and R. Purwaningrum, "Hubungan Pengetahuan Ibu Tentang Penanganan Diare Pada Balita Dengan Kecenderungan Ibu Membawa Balita ke Puskemas Sitopeng Kota Cirebon," Tunas Med. J. Kedokt. Kesehatan vol. 3, 2016.

[8] C.S. Sulistiyana and Y. Febriyanti, "Tingkat Kepuasan Pasangan Keluarga terhadap Pelayanan Manajemen Terpadu Balita Sakit (MTBS) di Puskesmas Sitopeng Kota Cirebon Jawa Barat," Tunas Med. J. Kedokt. Kesehatan, vol. 1, 2017

[9] D. Shah, P. Choudhury, P. Gupta, J.L. Mathew, T. Gera, S. Gogia, P Mohan, R. Panda, and S. Menon, "Promoting appropriate management of diarrhea: a systematic review of literature for advocacy and action UNICEF-PHFI series on newborn and child health," India Indian Pediatr., vol. 49, pp. 627-49, 2012. 
[10] C.L.F. Walker, S. Taneja, L.M. Lamberti, A. Lefevre, R. Black, and S. Mazumder, "Management of childhood diarrhea among private providers in Uttar Pradesh,” India J. Glob. Health, vol. 6, 2016.

[11] B.K. Desta, N.T. Assimamaw, and T.D. Ashenafi, "Knowledge, Practice, and Associated Factors of Home-Based Management of Diarrhea among Caregivers of Children Attending Under-Five Clinic in Fagita Lekoma District, Awi Zone, Amhara Regional State, Northwest Ethiopia, 2016," Nurs. Res. Pract., 2017

[12] K.Z. Lwin and I. Putra, "Mothers' knowledge of the causes and prevention associated with diarrhea among under-five children in Hlaing Thar Yar Township, Yangon, Myanmar," Glob. Heal. Manag. J. vol. 2, pp. 76-83, 2018.

[13] T. Joseph and P. Naregal, "A Study to Assess the Effectiveness of Health Education on Knowledge with Reference to Prevention and Home Management of Diarrhea among Mothers of under Five Children in Selected Rural Area at Karad Taluka,” Int J Sci Res vol. 3, pp. 1329 33, 2014.

[14] M.P.H. Sori Muda Sarumpaet, Analisis Faktor-Faktor Yang Berhubungan Dengan Kejadian Diare Untuk Menentukan Kebijakan Penanggulangan Diare Di Wilayah Kerja Puskesmas Kecamatan Mutiara Kabupaten Pidie Tahun 2003 (Master Thesis), Medan: Universitas Sumatera Utara, 2003.

[15] H.M. Haroun, M.S. Mahfouz, M. El Mukhtar, and A. Salah, "Assessment of the effect of health education on mothers in Al Maki area, Gezira state, to improve homecare for children under five with diarrhea," Journal of family and community medicine, vol. 17, no. 3 , pp. 141,2010 